\title{
Ape1 regulates WNT/ $\beta$-catenin signaling through its redox functional domain in pancreatic cancer cells
}

\author{
SHAOJIE JIANG ${ }^{1,2^{*}}$, LINA ZHU ${ }^{3 *}$, HAIMEI TANG ${ }^{4}$, MIAOFENG ZHANG $^{5}$,

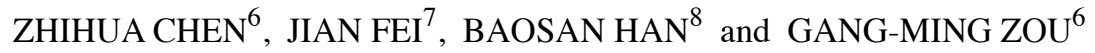

\begin{abstract}
${ }^{1}$ Department of Radiology, Sir Run Run Shaw Hospital, School of Medicine, Zhejiang University, Hangzhou, Zhejiang 310016; ${ }^{2}$ Shanghai Cancer Institute, Shanghai Jiao Tong University School of Medicine, Shanghai 200240; ${ }^{3}$ Department of Ophthalmology, Renji Hospital, School of Medicine, Shanghai Jiao Tong University, Shanghai 200127; ${ }^{4}$ Biomedical Research Center, Sir Run Run Shaw Hospital, School of Medicine, Zhejiang University, Hangzhou, Zhejiang 310016; ${ }^{5}$ Department of Orthopaedics, Second Affiliated Hospital, School of Medicine, Zhejiang University, Hangzhou, Zhejiang 310009; ${ }^{6}$ Xin Hua Hospital, Shanghai Key Laboratory for Pediatrics Gastroenterology and Nutrition, Shanghai Institute for Pediatrics Research, Shanghai Jiao Tong University School of Medicine, Shanghai 200092; ${ }^{7}$ Department of

Surgery, Ruijin Hospital, School of Medicine, Shanghai Jiao Tong University, Shanghai $200025 ;{ }^{8}$ Department of Surgery, Xinhua Hospital, Shanghai Jiao Tong University School of Medicine, Shanghai 200092, P.R. China
\end{abstract}

Received February 14, 2015; Accepted April 6, 2015

DOI: 10.3892/ijo.2015.3048

\begin{abstract}
Apurinic/apyrimidinic endonuclease 1/redox factor-1 (Ape1/Ref-1, Ape1) is a multifunctional protein that is upregulated in human pancreatic cancer. Apel redox domain plays an essential role in regulating the effects of reactive
\end{abstract}

Correspondence to: Dr Gang-Ming Zou, Shanghai Institute for Pediatrics Research, Xinhua Hospital, Shanghai Jiao Tong University School of Medicine, 1665 Kongjiang Road, Shanghai 200092, P.R. China

E-mail: gzou2013@gmail.com

Dr Baosan Han, Department of Surgery, Xinhua Hospital, Shanghai Jiao Tong University School of Medicine, 1665 Kongjiang Road, Shanghai 200092, P.R. China

E-mail: hanbaosan@126.com

*Contributed equally

Abbreviations: AP-1, activator protein 1; Ape1/Ref-1, apurinic/ apyrimidinic endonuclease $1 /$ redox factor-1; BER, base excision repair; Cdk5, cyclin-dependent kinase 5; CTCs, circulating tumor cells; Dvl, dishevelled; E3330, (2E)-2-[(4,5-dimethoxy-2-methyl-3,6dioxo-1,4-cyclohexadien-1-yl)methylene]-undecanoic acid; EMT, epithelial-mesenchymal transition; eNO, endothelial nitric oxide; HIF-1 $\alpha$, hypoxia inducing factor; IWR-1, 4-(1,3,3a,4,7,7a-hexahydro1,3-dioxo-4,7-methano-2H-isoindol-2-yl)-N-8-quinolinyl-benzamide; $\mathrm{NF}-\kappa \mathrm{B}$, nuclear factor kappa-light-chain-enhancer of activated $\mathrm{B}$ cells; NPM1, nucleophosmin; NRX, nucleoredoxin; PCP, planar cell polarity; ROS, reactive oxygen species; TRF2, telomeric repeatbinding factor 2; VEGF, vascular endothelial growth factor

Key words: Ape1, ROS, E3330, IWR-1, $\beta$-catenin oxygen species (ROS) generated during physiological metabolism and pathological stress. In the present study, we explored whether Ape1 and ROS affect WNT/ $\beta$-catenin signaling. We used E3330, a small molecule inhibitor of the redox activity of Ape1, and a siRNA approach to knock down Ape1, in two human pancreatic cancer cell lines. Inhibition of Apel resulted in growth suppression of pancreatic cancer cells, increased ROS levels, upregulation of $\beta$-catenin and c-myc and downregulation of cyclin D1. Consistent with these data, overexpression of Ape1 in pancreatic cancer cells reduced ROS and c-myc levels and increased cyclin D1 levels. Moreover, treatment of pancreatic cancer cells with $\mathrm{H}_{2} \mathrm{O}_{2}$ to induce oxidative stress resulted in upregulated ROS levels, decreased Apel at both the mRNA and protein level, and alterations in $\mathrm{WNT} / \beta$-catenin pathway components. Finally, treatment of pancreatic cancer cells with the WNT/ $\beta$-catenin inhibitor IWR-1 resulted in growth inhibition, which was greatly enhanced when combined with E3330 treatment. In summary, our results demonstrate that ROS is an important intracellular messenger that can modulate $\mathrm{WNT} / \beta$-catenin signaling. The present study provides interesting new insight into crosstalk between the redox function of Ape1 and WNT/ $\beta$-catenin signaling in cancer cells. Furthermore, our data show that the combination of Ape1 and WNT inhibitors enhanced the inhibition of pancreatic cell proliferation. These results provide a promising novel therapeutic strategy for treating pancreatic cancer in future.

\section{Introduction}

Pancreatic cancer is a leading cause of cancer-related death, largely due to metastatic dissemination, and it has the worst prognosis of any major tumor type, with a 5-year survival rate of $\sim 5 \%$ (1). Patients with pancreatic cancer respond poorly to existing chemotherapeutic agents and radiation due to the high degree of hypoxia in pancreatic tumors $(2,3)$. Hypoxia-inducible 
factor-1 $\alpha$ (HIF-1 $\alpha)$ and vascular endothelial growth factor (VEGF) are ROS-related proteins that are both regulated by Apel redox signaling (4). Furthermore, ROS have been shown to switch on hypoxia-dependent epithelial-mesenchymal transition (EMT) in cancer cells (5). Abnormal activation of the WNT/ $\beta$-catenin pathway is also associated with pancreatic cancer (6). Because ROS are important intracellular messengers that can modulate $\mathrm{WNT} / \beta$-catenin signaling by a redox mechanism (7), we hypothesized that there may be crosstalk between Ape1 redox signaling and WNT/ $\beta$-catenin signaling in pancreatic cancer cells.

Ape1 is a multifunctional protein that regulates a wide variety of important cellular functions (8). It functions as an apurinic/apyrimidinic endonuclease in base excision repair (BER) of DNA lesions and as a redox-modifying factor in eukaryotic transcriptional regulation (9-13). For example, the redox function of Apel can stimulate the DNA-binding activity of HIF-1 $\alpha$, nuclear factor kappa-light-chain-enhancer of activated B cells (NF- $\kappa \mathrm{B})$, activator protein 1 (AP-1), and p53 (12-16). A recent report also showed that Ape1 is an essential factor stabilizing telomeric DNA. Its deficiency is associated with telomere dysfunction and segregation defects in immortalized cells maintaining telomeres by either the alternative lengthening of telomere pathway or telomerase expression. The DNA repair and $\mathrm{N}$-terminal acetylation domains are required for Ape1 function at telomeres. Ape1 associates with telomere proteins in U2OS cells, and Ape1 depletion causes dissociation of telomeric repeat-binding factor 2 (TRF2) from telomeres (17). Ape1 also regulates endothelial nitric oxide (eNO) production and vascular tone (18), and interacts with nucleophosmin (NPM1) within nucleoli, where it not only plays a role in the rRNA quality control process, but also where its BER activity is stimulated in cells (19-21). Furthermore, Ape1 can be phosphorylated by cyclin-dependent kinase $5(\mathrm{Cdk} 5)$ complexes, thus, reducing its apurinic/apyrimidinic (AP) endonuclease activity, which results in the accumulation of DNA damage and contributes to neuronal death (22). Accumulating evidence suggests that Ape1 is upregulated in pancreatic cancers (23), and it can affect $\mathrm{WNT} / \beta$-catenin signaling target genes, such as cyclin D1 and $c-m y c$, in different ways $(24,25)$. In addition, small interfering RNA targeting Apel enhances the sensitivity of human pancreatic cancer cells to gemcitabine in vitro (26). Single nucleotide polymorphisms (SNPs) in the Apel gene are also associated with breast cancer risk in a Chinese population (27), suggesting Apel plays a role in multiple types of cancer. Nevertheless, the functional role of Ape1 in tumor pathogenesis and progression remains unclear.

In the present study, we define a critical pathway by which Ape1 regulates WNT/ $\beta$-catenin signaling through its redox function. Inhibition of the redox functional domain of Ape1 by E3330 resulted in the upregulation of $\beta$-catenin and its target gene c-myc, but not cyclin D1. The level of cyclin D1 was positively correlated with Ape1, but not c-myc. Treating cells with a combination of an Ape1 inhibitor and a WNT inhibitor was more effective at inhibiting pancreatic cell proliferation, compared with either inhibitor alone. These data indicate that using a combination of these inhibitors will enhance their efficacy in pancreatic cancer therapy.

\section{Materials and methods}

Cell lines. SW-1990 and Panc-1 were purchased from, and authenticated by the American Type Culture Collection (ATCC, Manassas, VA, USA). Cells were maintained at $37^{\circ} \mathrm{C}$ in $5 \% \mathrm{CO}_{2}$ and grown in Dulbecco's modified Eagle's medium (DMEM; HyClone, Logan, UT, USA) with $10 \%$ fetal bovine serum (FBS; Invitrogen, Carlsbad, CA, USA).

Plasmid construction. Cysteines 65 and 93 in human Ape1 were mutated using the Quick Change Site-Directed Mutagenesis kit (Stratagene, La Jolla, CA, USA) to generate Ape1 (C65/93A). Ape1 ( $\triangle$ NLS) encodes Ape1 with a 20-aa deletion of the putative N-terminal nuclear localization signal. All mutations and deletions were verified by DNA sequencing. Wild-type Ape1 (WT), Ape1 (C65/93A), and Ape1 ( $\Delta$ NLS) were cloned into the pDsRed-N1 expression vector by standard cloning methods, as previously described (18).

Cell transfections. SW-1990 cells were transfected with each Ape1 plasmid ( $2 \mu \mathrm{g}$ ) using Lipofectamine 2000 (Invitrogen). Forty-eight hours after transfection with plasmids, stable transfected cell lines were selected for by growing the cells in $\mathrm{G} 418(800 \mu \mathrm{g} / \mathrm{ml})$ for one month. The cells were imaged with a fluorescence microscope (Carl Zeiss, Oberkochen, Germany). The stable transfected cells were then harvested for analysis by RT-PCR, western blot analysis and flow cytometry.

RNA interference. SW-1990 and Panc-1 cells were transfected with $40 \mathrm{nM}$ siApel using Lipofectamine 2000 (Invitrogen), as described by the manufacturer. The siRNA sequence targeting human Ape1 was previously described (17). The transfected cells were maintained for $48 \mathrm{~h}$, and then harvested for analysis by RT-PCR and western blot analysis.

RNA isolation and RT-PCR. SW-1990 and Panc-1 cells were harvested after incubating with E3330 and/or IWR-1 for $48 \mathrm{~h}$. Total RNA was isolated using TRIzol reagent (Invitrogen) according to the manufacturer's instructions. Single-stranded cDNA was synthesized in a $20 \mu \mathrm{l}$ final volume containing $1 \mu \mathrm{g}$ of total RNA, $4 \mu \mathrm{l}$ of $5 \mathrm{X}$ reverse transcriptase buffer, $4 \mu \mathrm{l}$ of $2.5 \mathrm{mM}$ dNTP, $1 \mu \mathrm{l}$ of oligo-dT (100 pmol/ $\mu \mathrm{l}), 1 \mu \mathrm{l}$ of RNase inhibitor ( 4 units $/ \mu \mathrm{l}$ ), and $1 \mu \mathrm{l}$ of AMV reverse transcriptase (RT) $(5$ units $/ \mu \mathrm{l})$ at $42^{\circ} \mathrm{C}$ for $1 \mathrm{~h}$. Then, the reaction mixture was boiled for $5 \mathrm{~min}$ to inactivate the RT and quickly chilled on ice. The gene-specific primers used for PCR amplification are listed in Table I. PCR was performed using a thermal cycler (Applied Biosystems, Foster City, CA, USA). PCR products were analyzed by electrophoresis on a $1.5 \%$ agarose gel.

In vitro cell growth assay. In vitro growth assays were performed with SW-1990 and Panc-1 cells that were exposed to varying concentrations of E3330 and/or IWR-1. Briefly, either SW-1990 or Panc-1 cells were cultured in 96-well plates (4,000 cells/well) for $12 \mathrm{~h}$, treated with E3330 and/or IWR-1 which Diluted with DMSO at the indicated dose for $48 \mathrm{~h}$, and then the number of viable cells was determined using the nonradioactive Cell Counting kit-8 (CCK-8; Dojindo, Kyushu, Japan). All assays were repeated five times. 
Table I. Primers for RT-PCR.

\begin{tabular}{|c|c|c|c|}
\hline Gene & Primer sequence & Size (bp) & Temperature $\left({ }^{\circ} \mathrm{C}\right)$ \\
\hline \multirow[t]{2}{*}{ Apel } & Forward: ACTTCAGGAGCTGCCTGGACT & & \\
\hline & Reverse: AATGCAGGTAACAGAGAGTGGGA & 564 & 56 \\
\hline \multirow[t]{2}{*}{$\beta$-catenin } & Forward: TGATGGAGTTGGACATGGCCATGG & & \\
\hline & Reverse: CAGACACCATCTGAGGAGAACGCA & 570 & 62.5 \\
\hline \multirow[t]{2}{*}{$c-m y c$} & Forward: GCGTCCTGGGAAGGGAGATCCGGAGC & & \\
\hline & Reverse:TTGAGGGGCATCGTCGCGGGAGGCTG & 328 & 62.5 \\
\hline \multirow[t]{2}{*}{ Cyclin D1 } & Forward: GAGAACAAACAGATCATCCGCA & & \\
\hline & Reverse: GCTTCGATCTGCTCCTGG & 242 & 56 \\
\hline \multirow[t]{2}{*}{ GAPDH } & Forward: GAAGGTGAAGGTCGGAGTCA & & \\
\hline & Reverse: TTCACACCCATGACGAACAT & 402 & 60 \\
\hline
\end{tabular}

Western blot analysis. Cells were treated with E3330 and/or IWR-1 for $48 \mathrm{~h}$ and then lysed in RIPA buffer (Thermo Fisher Scientific, Waltham, MA, USA). Protein concentrations were measured using the BCA protein assay kit (Thermo Fisher Scientific). Samples were resolved through a $10 \%$ SDS-PAGE gel and transferred to PVDF membranes (Bio-Rad Laboratories, Hercules, CA, USA). The membrane was blocked in Tris-buffered saline containing $0.05 \%$ Tween-20 with 5\% non-fat skim milk for $1 \mathrm{~h}$ at room temperature, and then the membrane was incubated with primary antibody overnight at $4^{\circ} \mathrm{C}$. After three washes in Tris-buffered saline containing $0.1 \%$ Tween-20 (TBST), the membrane was incubated with horseradish peroxidase-conjugated secondary antibody for $1 \mathrm{~h}$ at room temperature. After three washes in TBST, the membrane was visualized by enhanced chemiluminescence using the ChemiDoc XRS+ imaging system (Bio-Rad Laboratories). The following antibodies were used: GAPDH, Ape1, $\beta$-catenin, cyclin D1 (Cell Signaling Technology, Danvers, MA, USA), and c-myc (Abcam, Burlingame, CA, USA).

Detection of reactive oxygen species by flow cytometry. Cells were treated with E3330 and/or IWR-1 for $48 \mathrm{~h}$, washed with PBS, and resuspended in DMEM. Then, the cells were incubated in $0.5 \mu \mathrm{M}$ DCFH-DA (Beyotime Institute of Biotechnology, Jiangsu, China) for $30 \mathrm{~min}$ at $37^{\circ} \mathrm{C}$. ROS fluorescence intensity was determined by flow cytometry with an excitation at $488 \mathrm{~nm}$ and an emission at $525 \mathrm{~nm}$ using a FACSCalibur flow cytometer (Becton-Dickinson, Franklin Lakes, NJ, USA).

Detection of cell cycle by flow cytometry. Cell cycle analysis was performed on SW-1990 and Panc-1 cells following a 48-h incubation with E3330 and/or IWR-1. The cells were fixed in chilled methanol overnight before staining with $50 \mu \mathrm{g} / \mathrm{ml}$ propidium iodide (Nanjing KeyGen Biotech, Co., Ltd., Jiangsu, China) in the presence of $20 \mu \mathrm{g} / \mathrm{ml}$ RNase (Beyotime Institute of Biotechnology) and 0.1\% NP-40 (Sigma). Analysis was performed immediately after staining using a FACSCalibur flow cytometer (Becton-Dickinson).

Statistical analysis. Statistical analysis was performed using a GraphPad Prism v5.0 statistical software package, and a
Student's test was used to test the probability of significant differences between samples. The cut-off for statistical significance was set at $\mathrm{P}<0.05$.

\section{Results}

Inhibition of Apel redox function with E3330 suppresses the growth of human pancreatic cancer cell lines through cyclin D1 downregulation. To determine the function of the Ape1 redox domain in human pancreatic cancer cells, we treated SW-1990 and Panc-1 cells with E3330, a small molecule inhibitor of the Ape-1 redox domain. We measured the in vitro growth of SW-1990 and Panc-1 cells that were exposed to increasing doses of E3330 using the Cell Counting kit-8 (CCK-8) assay (Fig. 1A). There was a significant inhibition in the growth of SW-1990 and Panc-1 cells at doses of $\mathrm{E} 3330>10 \mu \mathrm{mol} / 1$. Based on this result, we analyzed the level of the cell proliferation-related gene cyclin D1, and we found that cyclin D1 was reduced at both the mRNA and protein level with increasing concentrations of E3330 (Fig. 1B-E). These alterations in cyclin D1 levels were accompanied by the upregulation of ROS (Fig. 1F).

E3330 treatment upregulates WNT/ $\beta$-catenin signaling through upregulation of intracellular ROS levels. E3330 treatment of pancreatic cancer cell lines resulted in reduced levels of cyclin D1, a well-known WNT/ $\beta$-catenin target gene. Therefore, we examined the level of $\beta$-catenin, a key member of the WNT/ $\beta$-catenin signaling pathway, and another $\mathrm{WNT} / \beta$-catenin downstream target gene, c-myc. $\beta$-catenin and c-myc were upregulated at both the mRNA and protein level in an E3330 dose-dependent manner (Fig. 1B-E). ROS have been shown to function as intracellular messengers to augment WNT/ $\beta$-catenin signaling by modulating the redox-dependent interaction between nucleoredoxin (NRX) and dishevelled (Dvl) $(28,29)$. Therefore, we hypothesize that E3330 augments WNT/ $\beta$-catenin signaling by inhibiting the redox function of Ape1 and upregulating intracellular ROS levels.

The WNT/ $\beta$-catenin signaling inhibitor IWR-1 suppresses growth of pancreatic cancer cell lines. IWR-1 is a $\mathrm{WNT} / \beta$-catenin signaling inhibitor that induces stabiliza- 
A

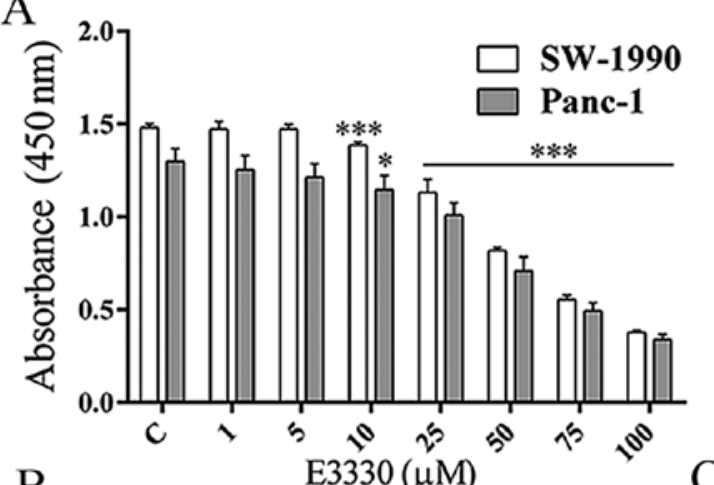

B

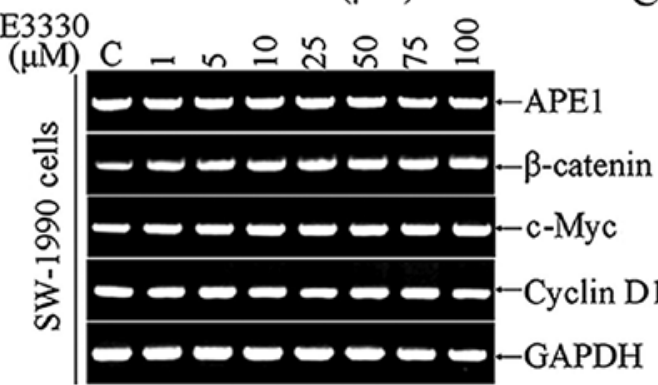

E3330

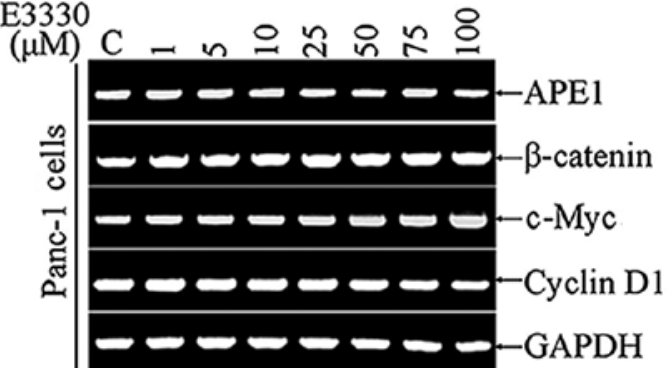

D E3330
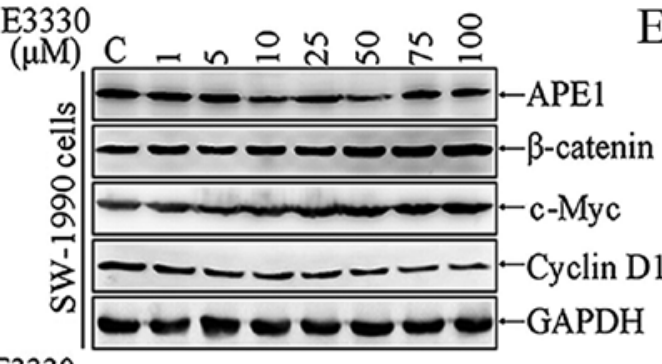

E E3330

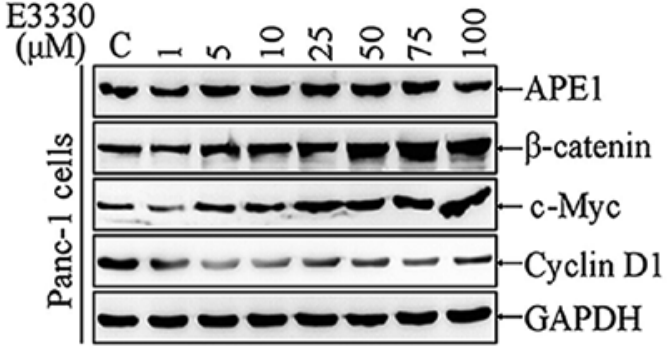

F

E3330

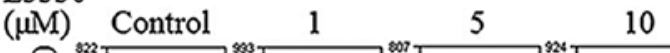
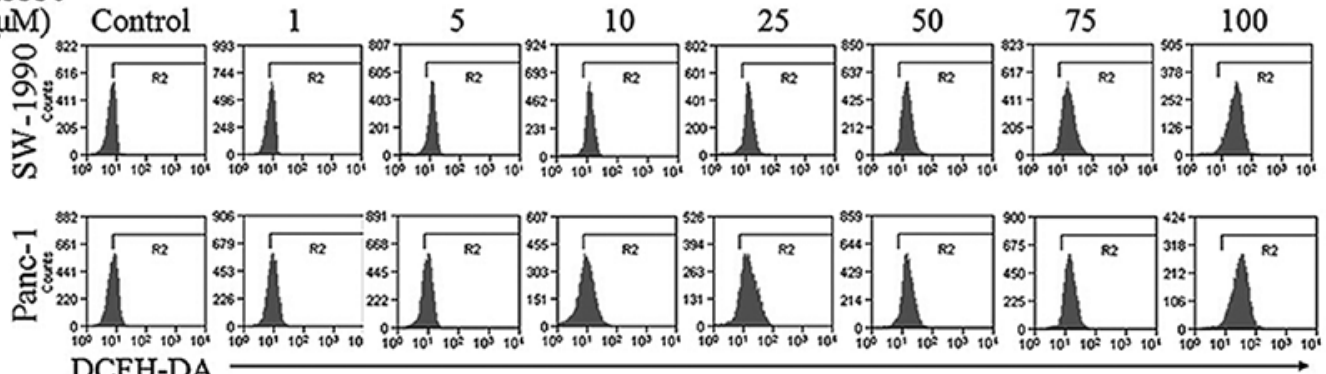

Figure 1. Inhibition of Ape1/Ref-1 redox activity upregulates WNT/B-catenin signaling, but downregulates cyclin D1. (A) The Ape1 redox domain inhibitor E3330 inhibited the in vitro growth of pancreatic cancer cells. SW-1990 and Panc-1 pancreatic cancer cells were treated with various doses of E3330 for 48 h, and control was treated with DMSO. The CCK-8 assay was performed to examine cell viability, and the standard deviations (SDs) of five independent experiments were calculated. The statistical significance between each group was calculated using a Student's t-test; ${ }^{*} \mathrm{P}<0.05,{ }^{* * * *} \mathrm{P}<0.001$. (B and C) Total RNA was extracted, and RT-PCR was performed with GAPDH as an internal control. (D and E) Total protein was extracted, and a western blot analysis was performed with GAPDH as an internal control. (F) The ROS levels in SW-1990 and Panc-1 cells that were exposed to E3330 for $48 \mathrm{~h}$ were determined using DCFH-DA and flow cytometry.

tion of Axin proteins via a direct interaction, thus leading to enhanced $\beta$-catenin destruction (30). To determine the effect of IWR-1 on the in vitro growth of SW-1990 and Panc-1 cells, we exposed each cell line to increasing doses of IWR-1 and measured growth effects using a CCK-8 assay (Fig. 2A). There was a significant inhibition in the growth of both SW-1990 and Panc-1 cells at doses of IWR-1 $>20 \mu \mathrm{mol} / 1$. WNT/ $\beta$-catenin signaling-associated protein levels were examined, and we found that $\beta$-catenin, c-myc and cyclin D1 were decreased with increasing doses of IWR-1 (Fig. 2D and E). However, the level of $\beta$-catenin mRNA was not altered (Fig. $2 \mathrm{~B}$ and C).
Combined treatment with E3330 and IWR-1 downregulates cyclin D1 more effectively and blocks G1-to-S progression. E3330 treatment suppressed the growth of pancreatic cancer cells and reduced levels of cyclin D1. However, E3330 treatment also increased WNT/ $\beta$-catenin pathway genes, such as $\beta$-catenin and c-myc. To determine whether inhibition of the WNT/ $\beta$-catenin pathway can enhance the growth suppressive effects of E3330, we treated pancreatic cancer cells with a combination of E3330 and IWR-1. SW-1990 and Panc-1 cells were exposed to varying doses of E3330 and IWR-1 in combination and growth effects were measured using 

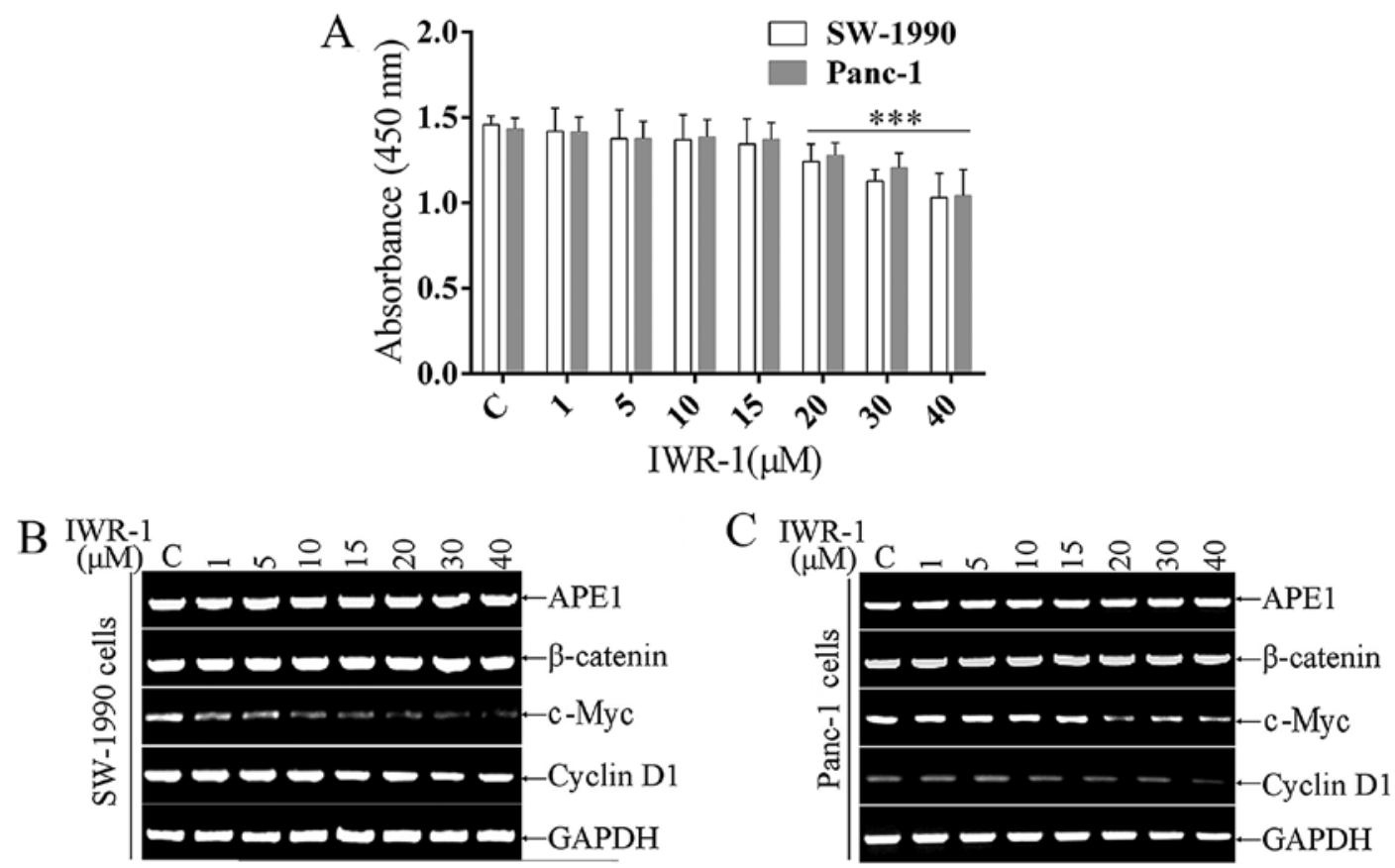

D IWR-1
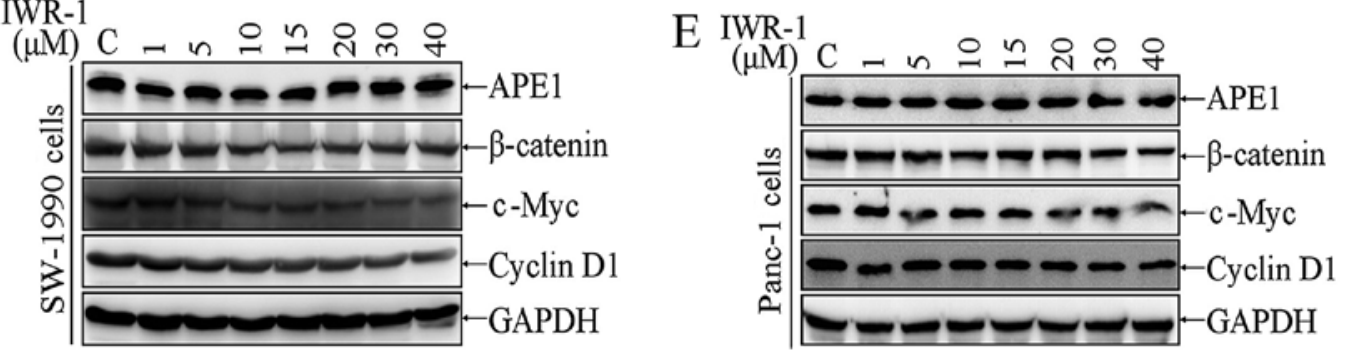

Figure 2. The WNT/ $\beta$-catenin inhibitor IWR-1 downregulates WNT/ $\beta$-catenin signaling and suppresses pancreatic cell growth. (A) The WNT/ $\beta$-catenin inhibitor IWR-1 inhibited the in vitro growth of pancreatic cancer cells. SW-1990 and Panc-1 pancreatic cancer cells were treated with varying doses of IWR-1 for $48 \mathrm{~h}$, and control was treated with DMSO. The CCK-8 assay was performed to examine cell viability, and the SDs of five independent experiments were calculated. The statistical significance between each group was calculated using a Student's t-test; ${ }^{* *} \mathrm{P}<0.01,{ }^{* * *} \mathrm{P}<0.001$. (B and C) Total RNA was extracted, and RT-PCR was performed with GAPDH as an internal control. (D and E) Total protein was extracted, and a western blot analysis was performed with GAPDH as an internal control.

the CCK-8 assay. There was a significant inhibition in the growth of SW-1990 and Panc-1 cells that were treated with IWR-1 (15 $\mu \mathrm{mol} / \mathrm{l})$ and E3330 $(10 \mu \mathrm{mol} / \mathrm{l})$ (Fig. 3A). Ape1 and WNT/ $\beta$-catenin signaling genes were examined by RT-PCR and western blot analysis. The upregulation of $\beta$-catenin and c-myc that was previously observed with E3330 treatment was effectively inhibited by the addition of IWR-1. Cyclin D1 downregulation was also enhanced by the combined inhibitor treatment, compared with that observed with individual inhibitor treatments (Fig. 3B-E). In addition, G1-to-S cell cycle progression was blocked with decreasing levels of cyclin D1 (Fig. 3G). These data suggest that E3330 and IWR-1 are promising candidates for a novel combinatorial therapeutic strategy.

Overexpression of Apel affects WNT/ $\beta$-catenin signaling and cellular ROS levels. To validate the role of Ape1 in WNT/ $\beta$-catenin signaling activation, we cloned wild-type Apel (WT) and two mutant Apel cDNAs into the pDsRed-N1 expression vector for overexpression studies (Fig. 4A). To generate mutant Ape1, we developed a construct with mutated redox-sensitive cysteines $(\mathrm{C} 65 / 93 \mathrm{~A})$, and a construct with a 20 -aa deletion of the putative N-terminal nuclear localization signal ( $\triangle \mathrm{NLS}$ ) of Apel. Each of these plasmids was transfected into SW-1990 cells. Ape1 (WT) and Ape1 (C65/93A) were largely localized to the nucleus, whereas Ape1 ( $\triangle$ NLS) was largely localized to the cytoplasm (Fig. 4B). The ROS levels in Ape1 transfected cells were determined using DCFH-DA and flow cytometry. Overexpression of Ape1 (WT) and Apel $(\Delta \mathrm{NLS})$, but not Apel (C65/93A), reduced the level of intracellular ROS (Fig. 4C). We examined the level of Ape1 and $\mathrm{WNT} / \beta$-catenin signaling genes by RT-PCR and western blot analysis. Overexpression of all of the Apel constructs in SW-1990 cells resulted in the downregulation of c-myc, but overexpression of Apel $(\Delta \mathrm{NLS})$ resulted in the greatest reduction of c-myc. Cyclin D1 was upregulated in SW-1990 cells expressing Apel (WT) and Apel ( $\triangle$ NLS), but not Ape1 (C65/93A). These alterations occurred both at the mRNA and protein level (Fig. 4D and E). We believe that c-myc downregulation may be due to the ability of Ape1 to cleave $c$-myc mRNA (31).

Apel is required for inhibiting $W N T / \beta$-catenin signaling. To confirm the function of Ape1 in WNT/ $\beta$-catenin signaling, Apel was knocked down by siRNA in SW-1990 and Panc-1 

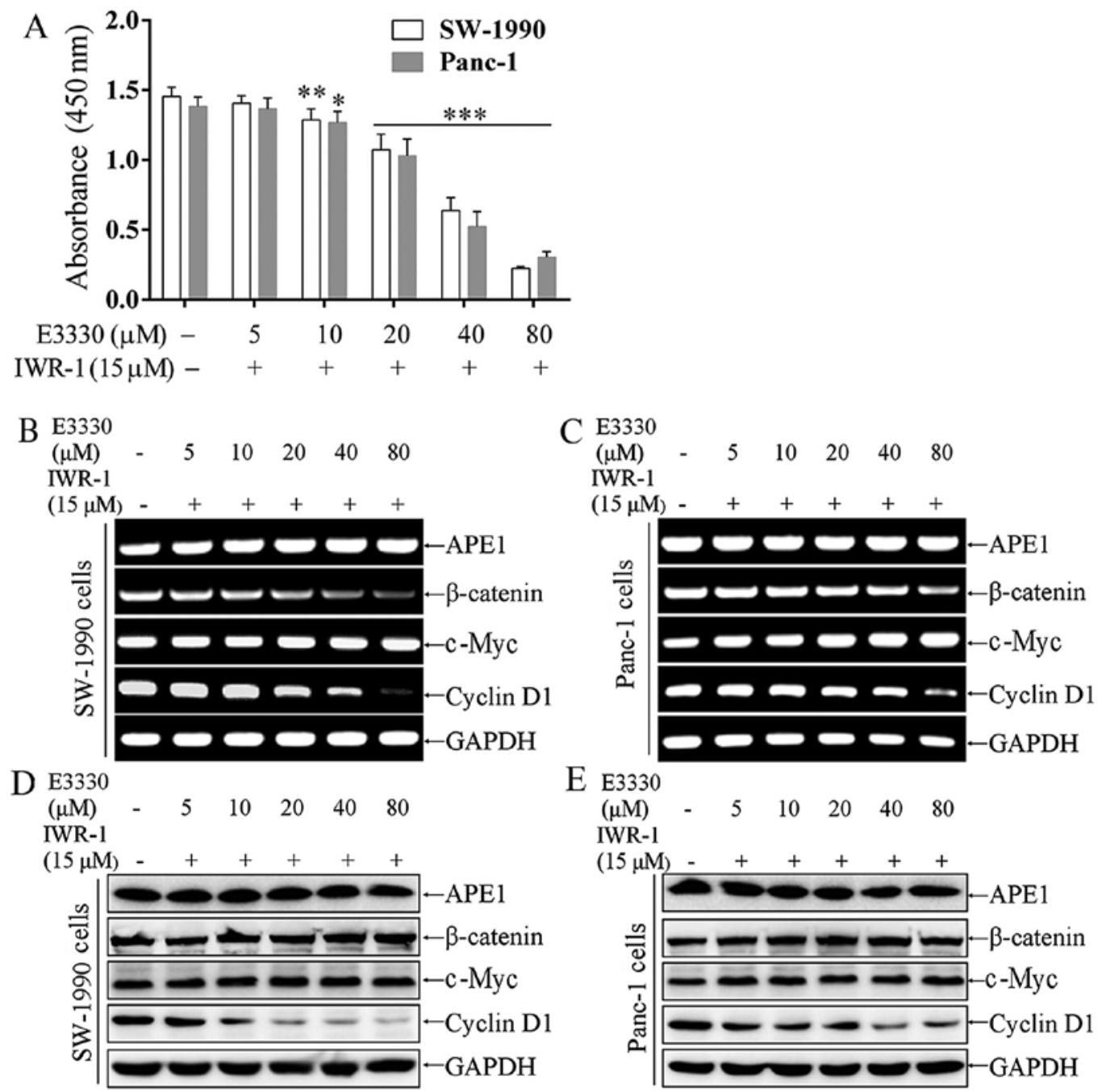

E E3330

$\begin{array}{lllllll}(\mu \mathrm{M}) & - & 5 & 10 & 20 & 40 & 80\end{array}$

IWR-1

$(15 \mu \mathrm{M})-+++++$
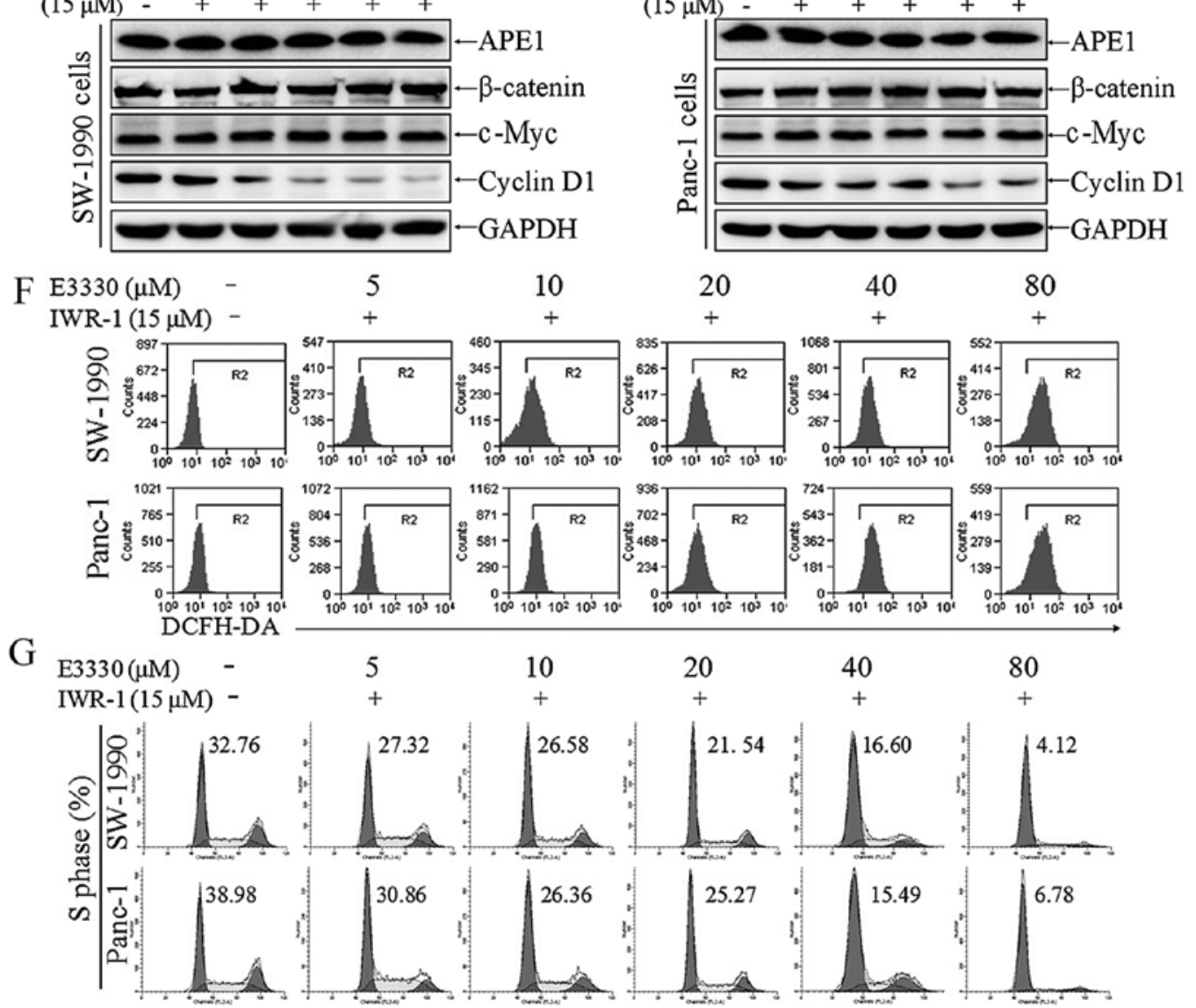

Figure 3. Combined treatment with E3330 and IWR-1 enhances the growth suppression of pancreatic cancer cells. (A) SW-1990 and Panc-1 pancreatic cancer cells were treated with varying doses of E3330 and IWR-1 for $48 \mathrm{~h}$, and control was treated with DMSO. The CCK-8 assay was performed to examine cell viability, and the SDs of five independent experiments were calculated. The statistical significance between each group was calculated using a Student's t-test; ${ }^{*} \mathrm{P}<0.05,{ }^{* * *} \mathrm{P}<0.01,{ }^{* * *} \mathrm{P}<0.001$. (B and C) Total RNA was extracted, and RT-PCR was performed with GAPDH as an internal control. (D and E) Total protein was extracted, and a western blot analysis was performed with GAPDH as an internal control. (F) The ROS levels in SW-1990 and Panc-1 cells, which were exposed to E3330 and IWR-1 for $48 \mathrm{~h}$, were determined using DCFH-DA and flow cytometry. (G) The DNA content is shown from SW-1990 and Panc-1 cells that were treated with DMSO (as control cells), or with E3330 and IWR-1 at varying doses for $48 \mathrm{~h}$. 
A

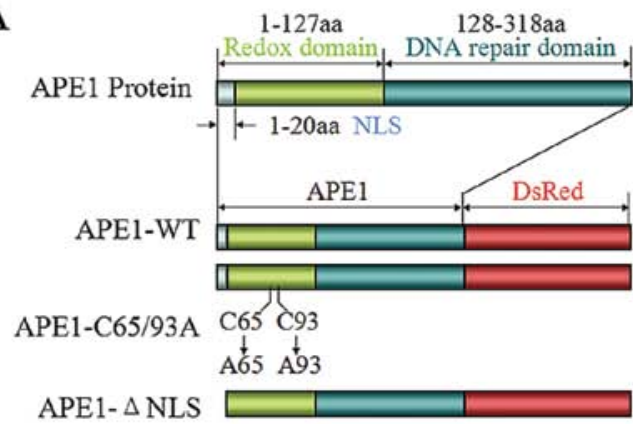

B

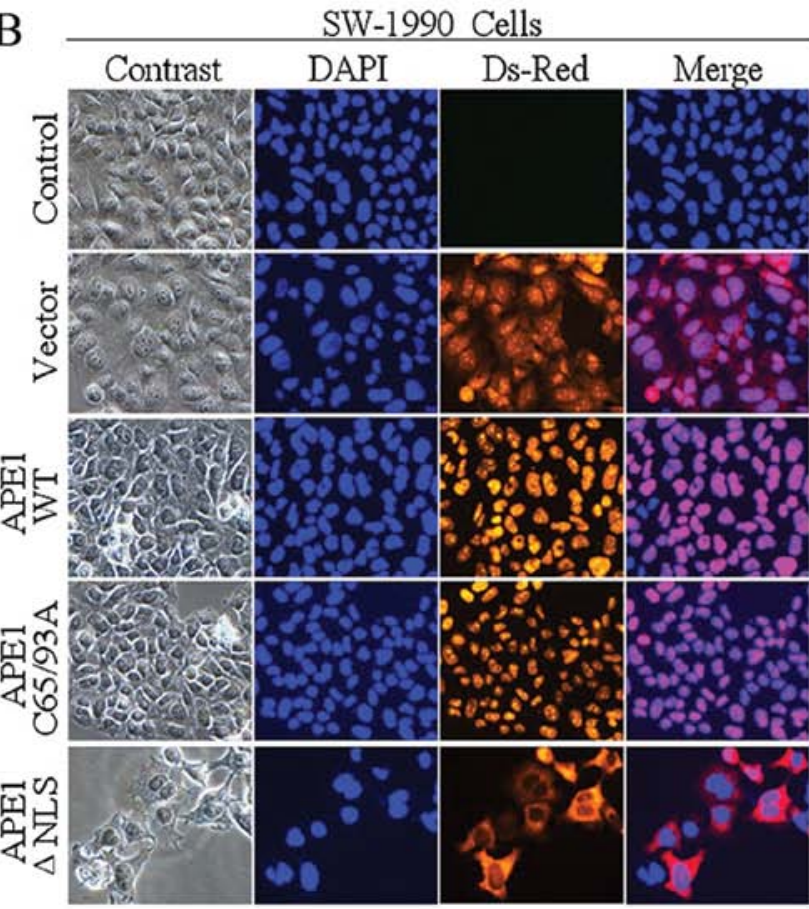

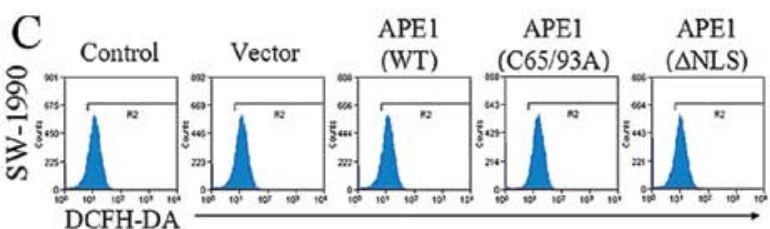
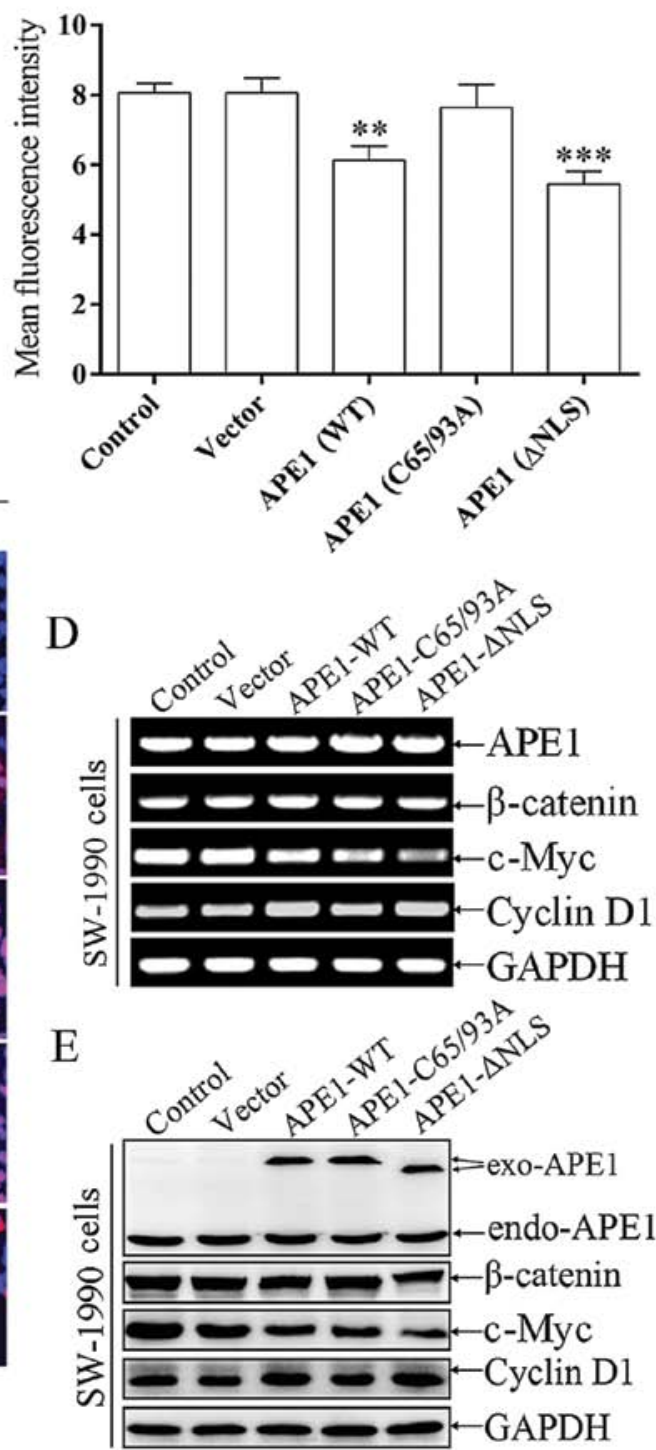

Figure 4. Overexpression of Ape1 in SW-1990 cells alters WNT/ $\beta$-catenin signaling. (A) This diagram shows the strategy of Apel expression vector construction. (B) SW-1990 cells were transfected with each plasmid and selected for using G418 for 1 month. (C) The ROS levels in Ape1 transfected cells were determined using DCFH-DA and flow cytometry, and the SDs of three independent experiments were calculated. The statistical significance between the cells expressing wild-type Ape1 and the mutant forms of Ape1 was calculated using a Student's t-test; ${ }^{* *} \mathrm{P}<0.01,{ }^{* * * *} \mathrm{P}<0.001$. (D) Total RNA was extracted, and RT-PCR was performed with GAPDH as an internal control. (E) Total protein was extracted, and a western blot analysis was performed with GAPDH as an internal control.

cells. Apel and several genes of the WNT/ $\beta$-catenin pathway were examined by RT-PCR and western blot analysis, and we found that $\beta$-catenin and $c$-myc were upregulated at protein level more than mRNA level (Fig. 5A and B), whereas cyclin D1 was downregulated both at the mRNA and protein level (Fig. 5A-D). These data further suggest that Apel is an inhibitor of WNT/ $\beta$-catenin signaling.

Apel is downregulated by high oxidative stress. To determine the effect of oxidative stress on Ape1, SW-1990 and Panc-1 cells were treated with increasing doses of $\mathrm{H}_{2} \mathrm{O}_{2}$ for $2 \mathrm{~h}$, and then cultured for $48 \mathrm{~h}$ to establish a hyperoxia model. ROS levels were upregulated in SW-1990 and Panc-1 cells, but cell viability was reduced as the concentration of $\mathrm{H}_{2} \mathrm{O}_{2}$ increased (Fig. 6A). We performed RT-PCR and western blot analysis, and unexpectedly found that Ape1 levels decreased as the concentration of $\mathrm{H}_{2} \mathrm{O}_{2}$ increased, at both the mRNA and protein level. In addition, $\beta$-catenin protein, but not mRNA, was upregulated, c-myc was upregulated at the mRNA and protein level and cyclin D1 was downregulated (Fig. 6B-E). The cyclin D1 promoter contains many transcription factor binding sites, including $\beta$-catenin/TCF and NF- $\kappa \mathrm{B}$ binding 
A
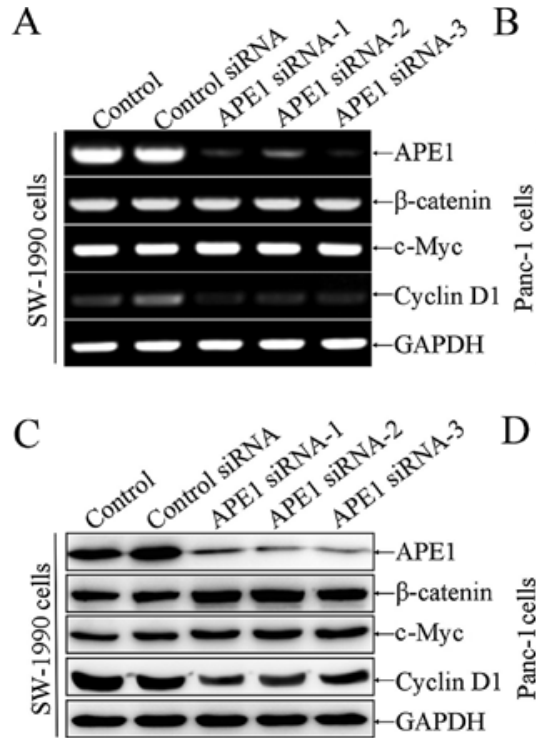

B

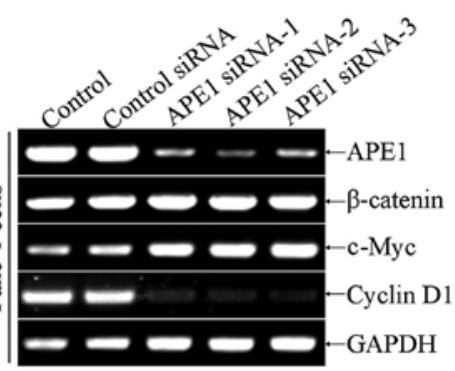

$\mathrm{D}$

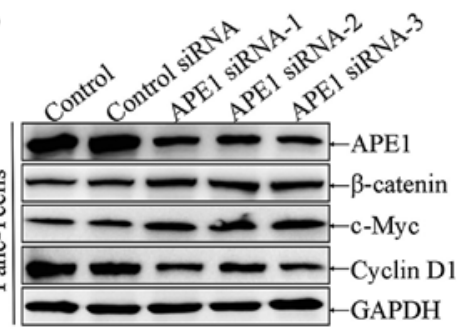

Figure 5. Ape1 knockdown alters WNT/ $\beta$-catenin signaling. (A and B) SW-1990 and Panc-1 pancreatic cancer cells were treated with the indicated siRNAs for $72 \mathrm{~h}$. Total RNA was extracted, and RT-PCR was performed with GAPDH as an internal control. (C and D) SW-1990 and Panc-1 cells were treated with the indicated siRNAs for $72 \mathrm{~h}$. Total protein was extracted, and a western blot analysis was performed with GAPDH as an internal control.

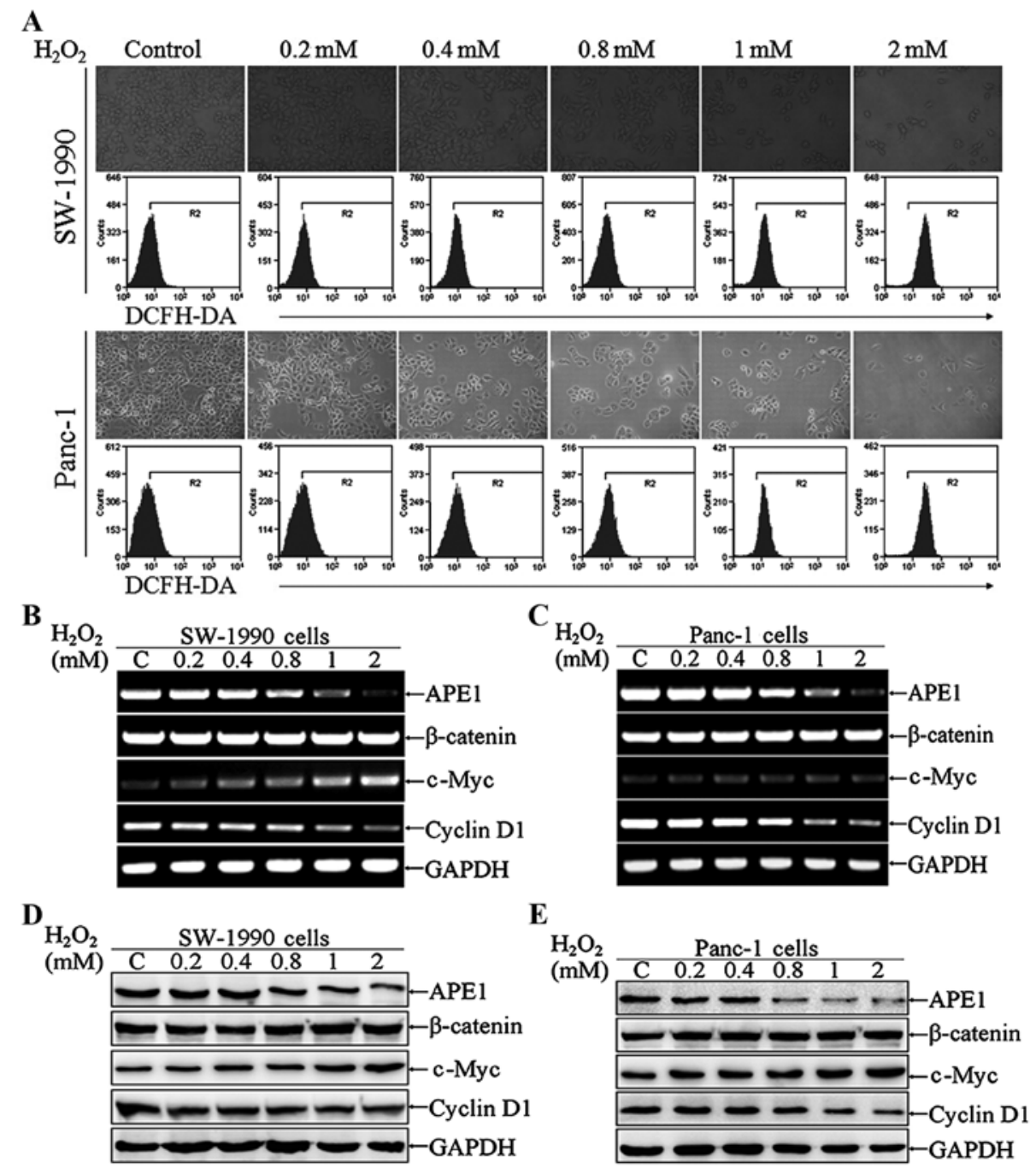

Figure 6. ROS induction by $\mathrm{H}_{2} \mathrm{O}_{2}$ treatment alters WNT/ $\beta$-catenin signaling. (A) SW-1990 and Panc-1 pancreatic cancer cells were treated with varying doses of $\mathrm{H}_{2} \mathrm{O}_{2}$ for $2 \mathrm{~h}$, and then cultured for $48 \mathrm{~h}$. Images were captured using a Nikon eclipse TS100 microscope carrying a pro-microscan camera with ScopePhoto software version 3.0. ROS levels in SW-1990 and Panc-1 cells, which were exposed to $\mathrm{H}_{2} \mathrm{O}_{2}$ for $2 \mathrm{~h}$ and then cultured for $48 \mathrm{~h}$, were determined using DCFH-DA and flow cytometry. (B and C) Total RNA was extracted, and RT-PCR was performed with GAPDH as an internal control. (D and E) Total protein was extracted, and a western blot analysis was performed with GAPDH as an internal control. 


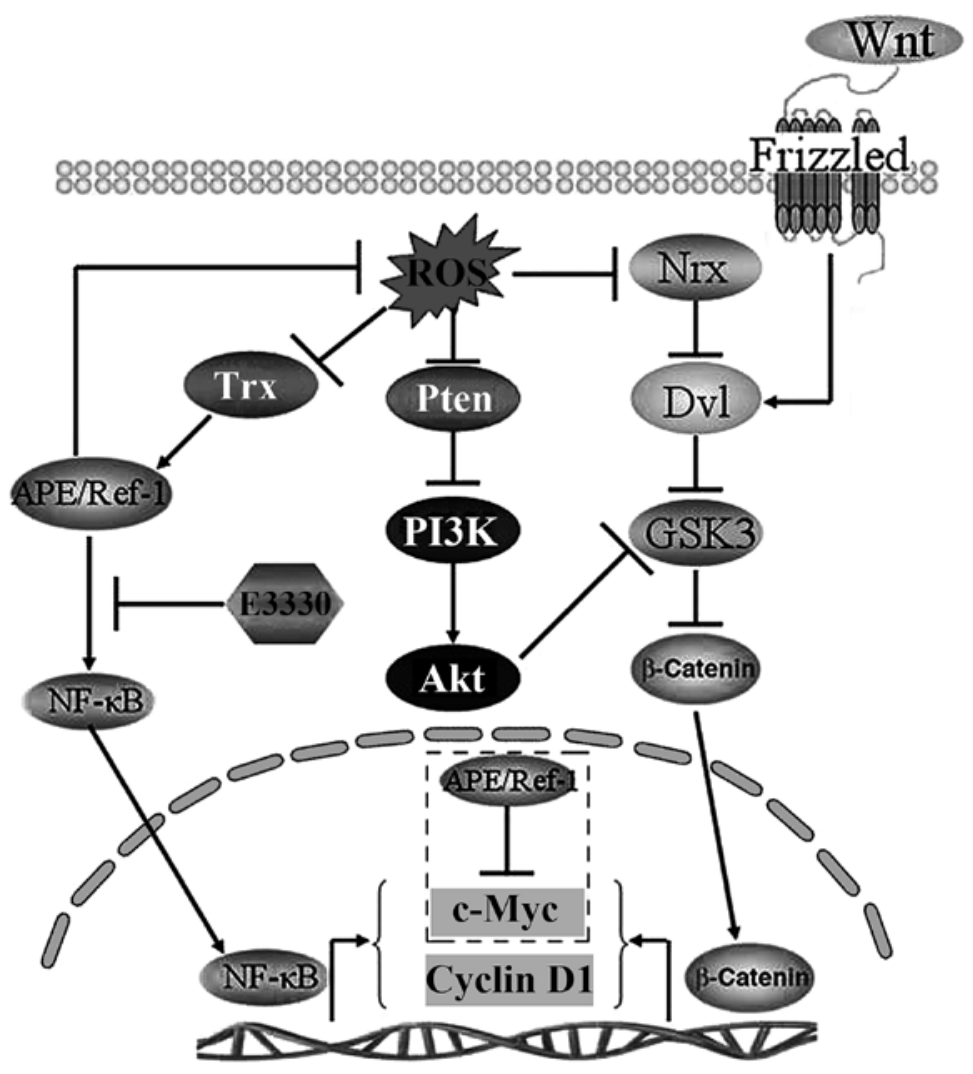

Figure 7. A proposed model highlights the role of Apel in regulating WNT/ß-catenin signaling.

sequences $(7,32)$. Because Ape1 can activate NF- $\mathrm{kB}$ through its redox activity (33), we believe that cyclin D1 expression is mainly controlled by NF- $\kappa \mathrm{B}$ signaling in pancreatic cancer cells (Fig. 7).

\section{Discussion}

Pancreatic cancer is the fourth most common cause of cancer-related deaths in the United States (34) and the twelfth worldwide. Pancreatic cancer has an extremely poor prognosis: for all stages combined, the 1- and 5-year relative survival rates are 25 and $6 \%$, respectively. Therefore, further study of this disease in cellular biology and pathophysiology may increase the possibility of finding new treatments, and consequently, improving the prognosis and survival of patients. We recently identified aberrant expression of Ape1 in pancreatic cancer cells (23) and colon cancer stem cells (27). In the present study, we begin to elucidate the function of Apel in pancreatic cancer cells and demonstrate crosstalk between the Ape1-mediated redox signaling and WNT signaling pathways. Furthermore, we show that treating pancreatic cancer cells with a combination of Apel and WNT inhibitors had an enhanced effect on growth inhibition.

Ape1 is a multifunctional protein involved in the maintenance of genomic integrity and in the regulation of gene expression. Pursuing Apel inhibition as a potential strategy for cancer cell therapy is justified, based on the following observations. Ape1 expression and activity are upregulated, or dysregulated, in many types of cancer, including prostate, bladder, ovarian, cervical, pancreatic, colon, and non-small cell lung cancer, as well as germ cell tumors. In addition, our previous studies demonstrated the role of Ape1 in regulating cancer cell growth and tumor angiogenesis in both pancreatic cancer $(4,23)$ and colon cancer stem cells $(27)$.

Because WNT signaling is also important in cancer cells, we wanted to determine whether Ape1 regulates $\mathrm{WNT} / \beta$-catenin signaling in cancer cells. WNT paracrine factors are cysteine-rich glycoproteins that bind to the Frizzled protein, a transmembrane receptor. The binding of WNT to its receptors can stimulate at least three distinct signaling pathways: the $\beta$-catenin pathway, the planar cell polarity (PCP) pathway, and the $\mathrm{Ca}^{2+}$ pathway (35). $\beta$-catenin is a central component of the WNT pathway, and it forms a complex with members of the TCF family of transcription factors in the nucleus to control the transcription of target genes (36). WNT signaling controls critical biological phenomena throughout development and in adult tissues, and it is a highly conserved pathway across all species. In parallel, aberrant WNT signaling underlies a wide range of pathologies in humans (37). Aberrant activation of WNT signaling is involved in the development of several epithelial tumors, including thyroid cancer (38). WNT signaling has been shown to regulate telomerase in cancer cells, and $\beta$-catenin has an important role in the maintenance of mitochondrial homeostasis (36). Importantly, WNT/ $\beta$-catenin signaling is aberrant in pancreatic carcinoma (39). The formation of non-adherent tumor spheres by human pancreatic cancer cells is associated with the upregulation of multiple WNT signaling genes, and pancreatic circulating tumor cells (CTCs) also show enriched expression of WNT signaling genes (40).

Redox balance underlies cellular homeostasis, and cancer initiation and progression has been linked to the disruption 
of redox balance and oxidative stress $(28,41)$. In the present study, we demonstrate that ROS can modulate signaling by the $\mathrm{WNT} / \beta$-catenin pathway. The present study provides interesting new insight into crosstalk between redox and WNT/ $\beta$-catenin signaling in normal physiology and cancer. The WNT/ $\beta$-catenin signaling pathway can be regulated by redox signaling through the redox-sensitive association of NRX with Dvl (28). NRX is a thioredoxin-related, redoxregulating protein that inhibits $\mathrm{WNT} / \beta$-catenin signaling through Dvl (7). Oxidative stress inhibits the interaction between NRX and Dvl, which suggests that treatment with $\mathrm{H}_{2} \mathrm{O}_{2}$ may activate $W N T / \beta$-catenin signaling by releasing the NRX-mediated block on Dvl activity. Therefore, ROS may augment WNT/ $\beta$-catenin signaling by modulating the redoxdependent interaction between NRX and Dvl (7).

Our previous study demonstrated that Ape1 is highly expressed in pancreatic cancer cell lines, and that inhibition of Apel redox activity significantly inhibits pancreatic cell proliferation (23). However, the question of whether Ape1-mediated redox signaling regulated the $\mathrm{WNT} / \beta$-catenin pathway in cancer cells remained unclear. Further questions regarding whether an Ape1 redox inhibitor could act synergistically with a WNT inhibitor in the growth inhibition of cancer cells also needed to be addressed. In the present study, we identified a regulatory role for Ape1 in WNT/ $\beta$-catenin signaling through its redox functional domain in pancreatic cancer cells. Our observations suggest that Apel acts as an inhibitor of WNT/ $\beta$-catenin signaling, because $\beta$-catenin was upregulated when Apel mRNA was depleted by siRNA. Furthermore, E3330 inhibition of the redox function of Ape1 in pancreatic cancer cells increased intracellular ROS levels and led to the upregulation of $\beta$-catenin. Although E3330 inhibited proliferation of pancreatic cancer cells, the increased $\beta$-catenin upon E3330 treatment could enhance cancer cell metastasis, which would ultimately result in a worse prognosis for the patient. Therefore, administration of E3330 alone in the treatment of pancreatic cancer is likely not ideal. We found that the combination of E3330 and the WNT/ $\beta$-catenin signaling inhibitor IWR-1, effectively blocked the upregulation of $\beta$-catenin upon E3330 administration, and enhanced the growth suppression of pancreatic cancer cells.

In summary, although E3330 inhibited SW1990 pancreatic cancer cell proliferation in a single dose, it also upregulated $\beta$-catenin expression in those cells, which may protect the cells from further growth inhibition. Therefore, a combination of an Ape1 and a WNT/ $\beta$-catenin inhibitor had a stronger effect in inhibiting pancreatic cell proliferation, indicating that this inhibitor combination may offer a more promising treatment option in pancreatic cancer therapy.

\section{Acknowledgements}

The present study was supported by the Shanghai Science and Technology Commision (11ZR1434800).

\section{References}

1. Haeno H, Gonen M, Davis MB, Herman JM, IacobuzioDonahue CA and Michor F: Computational modeling of pancreatic cancer reveals kinetics of metastasis suggesting optimum treatment strategies. Cell 148: 362-375, 2012.
2. Fishel ML, Jiang Y, Rajeshkumar NV, Scandura G, Sinn AL, He Y, Shen C, Jones DR, Pollok KE, Ivan M, et al: Impact of APE1/Ref-1 redox inhibition on pancreatic tumor growth. Mol Cancer Ther 10: 1698-1708, 2011.

3. Guillaumond F, Leca J, Olivares O, Lavaut MN, Vidal N, Berthezène $\mathrm{P}$, Dusetti NJ, Loncle $\mathrm{C}$, Calvo $\mathrm{E}$, Turrini $\mathrm{O}$, et al: Strengthened glycolysis under hypoxia supports tumor symbiosis and hexosamine biosynthesis in pancreatic adenocarcinoma. Proc Natl Acad Sci USA 110: 3919-3924, 2013.

4. Zou GM, Karikari C, Kabe Y, Handa H, Anders RA and Maitra A: The Ape-1/Ref-1 redox antagonist E3330 inhibits the growth of tumor endothelium and endothelial progenitor cells: Therapeutic implications in tumor angiogenesis. J Cell Physiol 219: 209-218, 2009.

5. Cannito S, Novo E, Compagnone A, Valfrè di Bonzo L, Busletta C, Zamara E, Paternostro C, Povero D, Bandino A, Bozzo F, et al: Redox mechanisms switch on hypoxia-dependent epithelial-mesenchymal transition in cancer cells. Carcinogenesis 29: 2267-2278, 2008.

6. Zhang Y, Morris JP IV, Yan W, Schofield HK, Gurney A, Simeone DM, Millar SE, Hoey $T$, Hebrok $M$ and Pasca di Magliano M: Canonical wnt signaling is required for pancreatic carcinogenesis. Cancer Res 73: 4909-4922, 2013.

7. Korswagen HC: Regulation of the Wnt/beta-catenin pathway by redox signaling. Dev Cell 10: 687-688, 2006.

8. Zou GM, Luo MH, Reed A, Kelley MR and Yoder MC: Ape1 regulates hematopoietic differentiation of embryonic stem cells through its redox functional domain. Blood 109: 1917-1922, 2007.

9. Mol CD, Izumi T, Mitra S and Tainer JA: DNA-bound structures and mutants reveal abasic DNA binding by APE1 and DNA repair coordination (corrected). Nature 403: 451-456, 2000.

10. Luo M, Delaplane S, Jiang A, Reed A, He Y, Fishel M, Nyland RL II, Borch RF, Qiao X, Georgiadis MM, et al: Role of the multifunctional DNA repair and redox signaling protein Ape1/Ref-1 in cancer and endothelial cells: Small-molecule inhibition of the redox function of Ape1. Antioxid Redox Signal 10: 1853-1867, 2008

11. Vasko MR, Guo C and Kelley MR: The multifunctional DNA repair/redox enzyme Ape1/Ref-1 promotes survival of neurons after oxidative stress. DNA Repair (Amst) 4: 367-379, 2005.

12. Fishel ML, He Y, Reed AM, Chin-Sinex H, Hutchins GD, Mendonca MS and Kelley MR: Knockdown of the DNA repair and redox signaling protein Ape1/Ref-1 blocks ovarian cancer cell and tumor growth. DNA Repair (Amst) 7: 177-186, 2008.

13. Tell G, Quadrifoglio F, Tiribelli C and Kelley MR: The many functions of APE1/Ref-1: Not only a DNA repair enzyme. Antioxid Redox Signal 11: 601-620, 2009.

14. Kelley MR and Fishel ML: DNA repair proteins as molecular targets for cancer therapeutics. Anticancer Agents Med Chem 8: 417-425, 2008.

15. Georgiadis MM, Luo M, Gaur RK, Delaplane S, Li X and Kelley MR: Evolution of the redox function in mammalian apurinic/apyrimidinic endonuclease. Mutat Res 643: 54-63, 2008.

16. Fishel ML, He Y, Smith ML and Kelley MR: Manipulation of base excision repair to sensitize ovarian cancer cells to alkylating agent temozolomide. Clin Cancer Res 13: 260-267, 2007.

17. Madlener S, Ströbel T, Vose S, Saydam O, Price BD, Demple B and Saydam N: Essential role for mammalian apurinic/apyrimidinic (AP) endonuclease Ape1/Ref-1 in telomere maintenance. Proc Natl Acad Sci USA 110: 17844-17849, 2013.

18. Jeon BH, Gupta G, Park YC, Qi B, Haile A, Khanday FA, Liu YX, Kim JM, Ozaki M, White AR, et al: Apurinic/apyrimidinic endonuclease 1 regulates endothelial NO production and vascular tone. Circ Res 95: 902-910, 2004.

19. Vascotto C, Fantini D, Romanello M, Cesaratto L, Deganuto M, Leonardi A, Radicella JP, Kelley MR, D'Ambrosio C, Scaloni A, et al: APE1/Ref-1 interacts with NPM1 within nucleoli and plays a role in the rRNA quality control process. Mol Cell Biol 29: 1834-1854, 2009.

20. Poletto M, Vascotto C, Scognamiglio PL, Lirussi L, Marasco D and Tell G: Role of the unstructured N-terminal domain of the hAPE1 (human apurinic/apyrimidinic endonuclease 1) in the modulation of its interaction with nucleic acids and NPM1 (nucleophosmin). Biochem J 452: 545-557, 2013. 
21. Vascotto C, Lirussi L, Poletto M, Tiribelli M, Damiani D, Fabbro D, Damante G, Demple B, Colombo E and Tell G: Functional regulation of the apurinic/apyrimidinic endonuclease 1 by nucleophosmin: Impact on tumor biology. Oncogene 33: 2876-2887, 2014

22. Huang E, Qu D, Zhang Y, Venderova K, Haque ME, Rousseaux MW, Slack RS, Woulfe JM and Park DS: The role of Cdk5-mediated apurinic/apyrimidinic endonuclease 1 phosphorylation in neuronal death. Nat Cell Biol 12: 563-571, 2010.

23. Zou GM and Maitra A: Small-molecule inhibitor of the AP endonuclease 1/REF-1 E3330 inhibits pancreatic cancer cell growth and migration. Mol Cancer Ther 7: 2012-2021, 2008.

24. Wang YT, Tzeng DW, Wang CY, Hong JY and Yang JL: APE1/Ref-1 prevents oxidative inactivation of ERK for G1-to-S progression following lead acetate exposure. Toxicology 305: 120-129, 2013.

25. Lee HM, Yuk JM, Shin DM, Yang CS, Kim KK, Choi DK, Liang ZL, Kim JM, Jeon BH, Kim CD, et al: Apurinic/apyrimidinic endonuclease 1 is a key modulator of keratinocyte inflammatory responses. J Immunol 183: 6839-6848, 2009.

26. Xiong GS, Sun HL, Wu SM and Mo JZ: Small interfering RNA against the apurinic or apyrimidinic endonuclease enhances the sensitivity of human pancreatic cancer cells to gemcitabine in vitro. J Dig Dis 11: 224-230, 2010

27. Lou D, Zhu L, Ding H, Dai HY and Zou GM: Aberrant expression of redox protein Ape1 in colon cancer stem cells. Oncol Lett 7: 1078-1082, 2014.

28. Funato $\mathrm{Y}$, Michiue $\mathrm{T}$, Asashima $\mathrm{M}$ and Miki $\mathrm{H}$ : The thioredoxin-related redox-regulating protein nucleoredoxin inhibits Wnt-beta-catenin signalling through dishevelled. Nat Cell Biol 8: 501-508, 2006.

29. Tetsu O and McCormick F: Beta-catenin regulates expression of cyclin D1 in colon carcinoma cells. Nature 398: 422-426, 1999.

30. Chen B, Dodge ME, Tang W, Lu J, Ma Z, Fan CW, Wei S, Hao W, Kilgore J, Williams NS, et al: Small molecule-mediated disruption of Wnt-dependent signaling in tissue regeneration and cancer. Nat Chem Biol 5: 100-107, 2009.
31. Barnes T, Kim WC, Mantha AK, Kim SE, Izumi T, Mitra S and Lee $\mathrm{CH}$ : Identification of Apurinic/apyrimidinic endonuclease 1 (APE1) as the endoribonuclease that cleaves c-myc mRNA. Nucleic Acids Res 37: 3946-3958, 2009.

32. Guttridge DC, Albanese C, Reuther JY, Pestell RG and Baldwin AS Jr: NF-kappaB controls cell growth and differentiation through transcriptional regulation of cyclin D1. Mol Cell Biol 19: 5785-5799, 1999.

33. Wu HH, Cheng YW, Chang JT, Wu TC, Liu WS, Chen CY and Lee H: Subcellular localization of apurinic endonuclease 1 promotes lung tumor aggressiveness via NF-kappaB activation. Oncogene 29: 4330-4340, 2010.

34. Hariharan D, Saied A and Kocher HM: Analysis of mortality rates for pancreatic cancer across the world. HPB (Oxford) 10: 58-62, 2008.

35. Kikuchi A, Kishida S and Yamamoto H: Regulation of Wnt signaling by protein-protein interaction and post-translational modifications. Exp Mol Med 38: 1-10, 2006.

36. Hoffmeyer K, Raggioli A, Rudloff S, Anton R, Hierholzer A, Del Valle I, Hein K, Vogt $R$ and Kemler R: Wnt $/ \beta$-catenin signaling regulates telomerase in stem cells and cancer cells. Science 336: 1549-1554, 2012.

37. Clevers $\mathrm{H}$ and Nusse $\mathrm{R}$ : Wnt/ $\beta$-catenin signaling and disease. Cell 149: 1192-1205, 2012.

38. Sastre-Perona A and Santisteban P: Role of the wnt pathway in thyroid cancer. Front Endocrinol (Lausanne) 3: 31, 2012.

39. Zeng G, Germinaro M, Micsenyi A, Monga NK, Bell A, Sood A, Malhotra V, Sood N, Midda V, Monga DK, et al: Aberrant Wnt/beta-catenin signaling in pancreatic adenocarcinoma. Neoplasia 8: 279-289, 2006.

40. Yu M, Ting DT, Stott SL, Wittner BS, Ozsolak F, Paul S, Ciciliano JC, Smas ME, Winokur D, Gilman AJ, et al: RNA sequencing of pancreatic circulating tumour cells implicates WNT signalling in metastasis. Nature 487: 510-513, 2012.

41. Grek CL and Tew KD: Redox metabolism and malignancy. Curr Opin Pharmacol 10: 362-368, 2010. 